\title{
Adıyaman ilinde hayvan hastalıklarının tedavilerine ilişkin folklorik uygulamalar**
}

\author{
Seda ÇAVUŞ ALAN ${ }^{1, a^{*}}$, Abdullah ERYOL ${ }^{2, b}$, Rahşan ÖZEN $N^{1, c}$ \\ ${ }^{I}$ Fırat Üniversitesi Veteriner Fakültesi, Veteriner Hekimliği Tarihi ve Deontoloji Ana Bilim Dalı, Elazığ, Türkiye \\ ${ }^{2}$ Tarım ve Orman Bakanlı̆̆l, Arpaçay İlçe Tarım ve Orman Müdürlüğü, Kars, Türkiye \\ ORCID: 0000-0002-4989-4813 ${ }^{a}$; 0000-0001-7960-7697 ${ }^{b}$;0000-0001-5788-0289
}

\section{MAKALE BILGGISI / \\ ARTICLE \\ INFORMATION: \\ Geliş / Received: \\ 03 Mart 2021 \\ 03 March 2021}

Kabul / Accepted:

26 Nisan 2021

26 April 2021

Anahtar Sözcükler:

Adiyaman,

Folklorik uygulamalar, Hayvan hastalıkları,

Veteriner hekimliği folkloru

Keywords:

Adiyaman,

Folkloric practice,

Animal diseases,

Veterinary folklore
ÖZET:

Çalışma, Adıyaman ilinde, halk arasında hayvan hastalıklarında kullanılan ilaç ham maddeleri ile bu hastalıklarda uygulanan folklorik uygulamaları belirlemek amacıyla yapıldı. Bu amaçla, Adıyaman'da hayvancılıkla uğraşan 81 kaynak kişiyle, gönüllülük esasına dayalı olarak yüz yüze görüşüldü. Veriler içerik analizi yöntemiyle değerlendirildi. Çalışmada, yörede, hayvan yetiştiriciliğinde ve hayvan hastalıklarının tedavisinde; hayvansal (tereyağı, yumurta, süt, yılan derisi vb.), bitkisel (hiro çiçeği, pirpirim, sumak vb.) ve madensel (göztaşı, sabun, mürekkep, tuz vb) kökenli ilaç ham maddelerinin kullanıldığı belirlendi. Hayvanlar huysuzlandığında, süt miktarı azaldığında, nazardan koruma amaçlı dini - sihri tedaviye başvurulduğu; muska yazdırıldığı, okunmuşşeker yedirildiği, nazar boncuğu veya gürgen ağacı dallarının boyun veya boynuzlarına asıldığı; bazı hastalık veya durumlarda (zehirlenme, sarılık, çıkık, yara vb.) kan akıtma, deri altına hava üfleme, dağlama gibi uygulamaların yapıldığı saptandı. Sonuç olarak, Adıyaman ilinin veteriner hekimliği folkloru açısından kökenleri Eski uygarlıklara ve baytarnamelere uzanan zengin bir birikime sahip olduğu, yörede hayvan hastalıklarının tedavisinde hala ampirik ve dini-sihri yöntemlerin uygulandığı ayrıca günümüz modern tedavi yöntemlerine benzer uygulamaların da yapıldığı ileri sürülebilir.

\section{Folkloric practices regarding treatment of animal diseases in Adryaman}

\section{ABSTRACT:}

This study was carried out to determine pharmaceutical raw materials used in animal diseases and the folkloric practices for animal diseases in Adiyaman. For this purpose, 81 people engaged with animal breeding in Adiyaman province were interviewed by face to face on a voluntary basis. Data were evaluated by content analysis method. This study revealed that for the purpose of animal breeding and treatment of animal diseases; animal origin (butter, milk, eggs, snakeskin etc), herbal (hiro flower, pursley, sumac etc) and mineral origin (bluestone, soap, ink, salt etc) pharmaceutical raw materials were used in that region. Religious-magic treatment rituals such as amulet writing, feeding with talismanic sweets or hanging the hornbeam tree branches or evil eye on the neck or horns are used when animals are restless, the amount of milk decreases and in order to protect from whammy. Applications such as cupping, air blowing under the skin and etching are applied in some diseases or events like poisoning, jaundice, dislocation, wound etc. As a result, this study shows that Adiyaman has a rich cultural background that extends to ancient civilizations and old veterinary manuscript. Beside modern treatment methods, empirical and religious-magic treatments are still using to cure animal diseases in this region.

How to cite this article: Alan SÇ, Eryol A, Özen R: Adıyaman ilinde hayvan hastalıklarının tedavilerine ilişkin folklorik uygulamalar. Veteriner Hekimler Dernegi Dergisi, 92(2): 159-172, 2021, Doi: 10.33188/vetheder.890468

\footnotetext{
**Bu çalışma 16-18 Nisan 2019 tarihinde, 3. International Conference on Agriculture, Food, Veterinary and Pharmacy Sciences (ICAFOP) kongresinde sözlü bildiri olarak sunulan "Pharmaceutical Raw Materials and Treatment Methods Used in Veterinary Folklore in Adlyaman Region" adlı çalışmanın genişletilmiş halidir.

* Sorumlu Yazar e-posta adresi / Corresponding Author e-mail address: scavus@firat.edu.tr
} 


\section{Giriş}

İnsanoğlunun tedavi edici maddeleri ilk olarak ne zaman ve ne şekilde kullandığ 1 kesin olarak tarihlendirilememekle beraber, Mezopotamya, Mısır, Hint ve Çin uygarlıklarında, hayvanların tedavilerinde bitkisel, hayvansal ve mineral kaynaklı droglardan yararlanıldığı bilinmektedir $(18,26)$. Bu ilaç uygulamaları, zamanla ampirik bilgilerden arınarak, bilimsel temellere dayandırılmış; bugün modern uygulamalardaki yerini almıştır (27). Günümüzde hızla değişen teknoloji ile birlikte "Modern" hekimlik bilgilerinin hızla gelişmesine rağmen, yüzyıllardır kuşaktan kuşağa aktarılan ve aktarılmaya devam eden halk hekimliği bilgilerinin ve tedavi yöntemlerinin de kullanımına devam edildiği görülmektedir (28). İnsanların hem kendileri hem de hayvanlarının tedavisi için, modern tıbba karşı güvenlerinin azalması, geçim sıkıntısı, artan hekim ve ilaç masrafları gibi çeşitli nedenlerden dolayı, geleneksel uygulamalara son yıllarda hızlı bir dönüş göze çarpmaktadır $(19,28)$. Öyle ki halk arasında ilk defa karşılaşılan hayvan hastalıklarında, genel olarak uygulanan ve tecrübeyle sabitlenmeyen tedaviler yapılmamakta ve böyle durumlarda hayvanlar çoğunlukla kesme yoluna gidilmektedir (19). Çalışma alanımız Adıyaman, Güneydoğu Anadolu Bölgesinde Orta Fırat Havzası içinde yer alır. Kuzeyinde Anti-Toros Dağları, güneyinde ise Fırat Nehri bulunmaktadır. İlçelerinin bir kısmı Doğu Anadolu ve Akdeniz Bölgesinde sayıldığından bu üç bölgenin de bitki örtüsü özelliklerini göstermektedir. Grid kareleme sistemine göre ise B7, C6 ve C7 karelerinde bulunur (15). Yöre halkı geçiminin büyük kısmını tarım ve hayvancılıkla sağlamaktadır. Coğrafi konumu nedeniyle tarih boyunca birçok medeniyete ve kültüre de ev sahipliği yapmış olan Adıyaman, zengin bir floristik yapıya ve kültürel birikime sahiptir (16). Çalışma, Adıyaman ilinde halk arasında hayvan hastalıklarında kullanılan ilaç ham maddeleri ile hayvan hastalıklarının tedavilerine ilişkin folklorik uygulamaları belirlemek amacıyla yapılmıştır.

\section{Gereç ve Yöntem}

Çalışmada 2017-2018 yılları arasında, Adıyaman'da yaşayan yöre halkının hayvan hastalıklarında kullandıkları ilaç ham maddeleri, kullanım şekilleri ve tedavi yöntemlerini belirlemek amacıyla yaşları 25 ile 72 arasında değişen 81 kişi ile gönüllülük esasına dayalı olarak yüz yüze görüşüldü. Çalışmanın hangi amaçla yapıldığı, isim ve bilgilerinin kullanılacağı konusunda katılımcılar bilgilendirilip, onam alındıktan sonra, yazarlar tarafından geliştirilen yarı yapılandırılmış görüşme formu kullanıldı. Kaynak kişilerin isimleri metin içinde (KK1, KK2..) şeklinde gösterildi. Ayrıca Ek-1'de yer alan “Kaynak Kişi Listesi”nde ayrıntılı bilgileri verildi. Yörede hangi hastalıklarda hangi ilaç ham maddelerinin kullanıldı̆̆ folklorik uygulamalar belirlendi. Veriler içerik analizi yöntemiyle değerlendirildi.

\section{Bulgular}

Katılımcıların \% 2'si (n=2) kadın, \% 98'i (n=79) erkek olarak tespit edilmiştir. Ankete katılanların \%31'inin (n=25) 35-44 yaş aralı̆̆ında yer aldığı görülmüştür. Eğitim durumlarına bakıldığında; büyük çoğunluğun (\% 49) (n=40) ilkokul mezunu olduğu anlaşılmaktadır.

\section{Hayvan Hastalıkları ve Folklorik Uygulamalar:}

Konjunktivitis: Büyük ve küçükbaş hayvanlarda rastlanır. Özellikle koyunlarda gözler iltihaplandığında veya çok yaşardığında, aktığında günde 2 defa $2 \mathrm{ml}$ kadar tuzlu su göze damlatılır (EK1-KK3,72). Hastalığın tedavisinde daha çok tuz kullanılır. Tereyağı, zeytin (Olea europaea) yağ1 ve tuz (EK1-KK33), tuz ve yoğurt (EK1KK35,65,67,71,75), tuz ve ayran (EK1-KK52,62,63) karışımları göze sürülür. Göze tuzlu su püskürtülür (EK1KK43,54,70) veya tuz da üflenir $(E K 1-K K 47,54)$. Bir başka tedavi yönteminde üç gün sabah akşam göze tükürülür (EK1-KK14) ya da bir kişi aç olarak ağzına tuzlu su alır, göze tükürülür (EK1-KK23,49,61,66).

Katarakt: Halk arasında "göze beyazllk inmesi” (EK1-KK17), “dumanl göz” (EK1-KK21), "göz beyazlamasl" (EK1-KK30,56), "gözde dumanlaşma” (EK1-KK37,72,81), "göz buğulanması” (EK1-KK40) olarak adlandırılır. 
Büyük ve küçükbaş hayvanlarda, yarım çay kaşığı tuz ağıza alınıp iyice eritilir, hayvanın gözüne tükürülür. Günde 1 kez iki üç gün bu uygulama yapılır (EK1-KK17). Göze tuzlu ayran (EK1-KK21,30,56), tuzlu su (EK1-KK56) ya da sadece tükürük (EK1-KK37) tükürülür (EK1-KK21,30,37,56). Cam kırıklar1 (EK1-KK41), cam kırılıp elekten geçirilerek elde edilen toz hayvanın gözüne üflenir (EK1-KK41,69,71). Göze limon (Citrus limon) s1k1lır (EK1KK72) ya da sarımsak (Allium sativum), yoğurt ve tuz karışımı göze sürülür (EK1-KK32,81).

Coenurus cerebralis: Hastalığa yakalanan koyunlar "hayvan delirdi" diye tanımlanır (EK1-KK4,21,27,51,55). Koyunlar kendi etrafinda döner. Bu hayvanlara ilaç kullanılmaz. Hocaya okutulur (EK1-KK21), hayvana muska yapılıp boynuna (EK1-KK4,27,51,55) veya boynuzuna bağlanır (EK1-KK4,51).

Boynuz Kırı̆̆g: Küçükbaş hayvanlarda boynuz kırıklarına rastlanır. Kanayan yere domates (Solanum lycopersucum) salçası (EK1-KK1,50,76) veya balmumu (EK1-KK52) sürülür (EK1-KK1,50,52,76). Balmumu bölgenin hava almasını engelleyerek kanamayı durdurur (EK1-KK52). Bol tuzlu su ile bez 1slatılır, kırık olan bölgeye sarılır. Alçı gibi kurur. Kırık 3-4 günde iyileşir (EK1-KK37). Ayrıca gres ya da yanık motor yağı üç gün boyunca uygulanır (EK1-KK48).

Apse: Yörede açllmamış iltihaplı şişliklere "apse" ya da "şiş" denir. Soğan (Allium cepa) kaynar suda haşlanıp (EK1-KK1,14,24) / közlenip (EK1-KK11) şişin üzerine koyup sar1lır. 24 saat (EK1-KK1,24) veya 2 gün (EK1KK14) bekledikten sonra açıldığında iltihap boşalmış olur (EK1-KK1,11,14,24). Büyükbaş hayvanlarda "kara sakız ă̆acı"nın (Pistacia terebinthus) bir dalı (yaprakları da dahil) 3 litre suda bir tane "iro çiçeği”" (hiro) (Alcea striata) ile birlikte 3-4 saat kaynatılır. İçinden ağaç dalı çıkarılır, bir beze sürülür, apsenin üstüne sarılır (EK1-KK10). Yine ağaç sakızı "menengiç" (Pistacia terebinthus) bir tutam sabun ile birlikte dövülür, apse oluşan bölgenin üzerine konur. İki gün sonra apse patlar (EK1-KK15). Menengiç ağacı (Pistacia terebinthus) yaprağı kaynatılır, apse üzerine bağlanırsa (EK1-KK23) veya menengiç ağacının (Pistacia terebinthus) sakızı apse üzerine sürülürse (EK1-KK24) kısa zamanda apseyi patlatır (EK1-KK23,24). Bir başka yöntemde kabak (Cucurbita sp.) haşlanarak sarg1 bezinin üzerine sürülür, apse üzerine kapatılır. 2-3 gün sonra açıldığında iltihap akar (EK1-KK11,19). "Gilicok” (Anchusa azurea), macun haline getirilir, kan kırmızı renk alınca apseye sürülür (EK1-KK57).

Keçilerde apse olduğunda iki tane yumurta sarısı apsenin üzerini kapatacak kadar hamura (buğday: Triticum aestivum) eklenir. Bu hazırlanan hamur karışımı 24 saat apse üzerinde bırakılır (EK1-KK16). Yarım kilo kadar "dolık" (Malva neglecta) suda haşlanıp, ineklerde oluşan apsenin üzerine konulur, temiz bir bezle sarılır. Bir gün sarılı vaziyette bekletilir, sonra sargı açılır (EK1-KK17). Yılan derisi apse üzerine sarılır (EK1-KK19). Apsenin üzeri tıraş edilip insan dışkısı sürülür (EK1-KK24). Şişlik üzerine vazelin sürülür (EK1-KK38). Apse kızgın demirle dağlanır (EK1-KK46). Dut (Morus sp.) pekmezi kaynatılır lokum kıvamını alınca apse üzerine konur, birkaç günde patlatır (EK1-KK53). Yulaf (Avena L.) veya "küşne” (Vicia sp.) ile bulamaç yapılır apse üzerine sürülür (EK1KK60). Ayakta şişlik olduğunda iğne ateşte kızdırılıp, şiş delinir sonra üzerine soğan (Allium cepa) bağlanır, 1 haftada düzelir (EK1-KK63). Hayvan kedi pisliği yediğinde ortaya çıkar (KK12). İki ya da üç baş soğan dilimlenip ekmek arasına konularak 1 defalığına yedirilir (EK1-KK12).

Aktinomikoz: İneklerde ve koyunlarda "domuzbaşı" olarak adlandırılır (EK1-KK13,31,76). Hayvanın yüz veya çenesinde şişen yere 10 gr kadar ağaç sakızı "menengiç” (Pistacia terebinthus) 40 gr kadar sabun ile birlikte dövülür, şişlik oluşan bölgenin üzerine konur. Karışım 1-2 gün boyunca bekletilir, apse patlar (EK1-KK13). Yoncaya benzer “buy otu, boy otu” (çemen otu)'nun (Trigonella sp.) kökü ezilir, domuzbaşının olduğu yere bezle bağlanır (EK1KK31). Bir tahta parçasının üzerine şişkinliği sınırlayacak şekilde dört çivi çakılır, şişkinliğe bastırılır, çivilere ipler bağlanarak tahtanın hareket etmesi engellenir, bu şekilde şişliğin dağılması beklenir (EK1-KK39). Şişlik iğne ile patlat1lır (EK1-KK76). Dua okunur (EK1-KK31).

Deri yaralanmaları: Büyük ve küçükbaş hayvanlarda vücudun çeşitli yerlerinde deri yaralanmaları görülür (EK1KK53,63) Yanmış motor yağ1, deri yara ve çatlaklarında günde 1 kez 3 gün boyunca o bölgeye sürülür (EK1- 
KK4,54,65). Zeytin (Olea europaea) yağ 5 gün boyunca deriye sürülür (EK1-KK4,15). Bir dilim kabak (Cucurbita sp.) 1 litre suda haşlanır, suyu hayvana içirilirken kabak da yaranın üzerine konup bağlanır (EK1-KK8). Yanmış motor yağ1 (EK1-KK9), katran (EK1-KK54), gres yağ1 (EK1-KK44), mürekkep (EK1-KK44) sürülür (EK1KK9,44,54). "Sinir otu” (geviş otu) (Plantago sp.) 250 gram kadar iyice ezilir yaranın tamamını kapatacak şekilde yara üzerine konulur. İki gün bu şekilde beklenir (EK1-KK13). "Dolık” otu (Malva neglecta) ezilir yaraya sürülür (EK1-KK63). Yara üzerine ayçiçek (Helianthus annuus) yağ1 sürülür ve 3 gün sarılır (EK1-KK34). Yara üzerine ya domates (Solanum lycopersucum) salçası beze sürülerek yara üzerine kapatılır (EK1-KK43,64) ya da acı kırmızı biber (Capsicum annuum) salçası, "sımak" (Rhus coriaria) karıştırılarak sürülür (EK1-KK41). Meşe ağacının (Quercus sp.) meyvesi "mazl” dövülerek toz haline getirilir günde bir kez yara üzerine dökülür (EK1-KK47). Kimi yerlerde "menengiç” (Pistacia terebinthus) sakızı veya erik ağacının (Prunus sp.) sakızı (EK1-KK53) sürülür (EK1KK49,53,55). Ayrıca kayısı (Prunus armeniaca) ve erik ağacının (Prunus sp.) sakızları birlikte kaynatılır, yaraya bastırılınca iyileşir (EK1-KK53). Bir başka uygulama da pekmez [dut (Morus sp.) / üzüm (Vitis sp.)] ile yapılır. Pekmez kaynatılıp yapışkanlaşınca yara üzerine sürülür (EK1-KK53). Kurumuş hayvan derisinin bir parçası öğütülüp toz haline getirilip yaraya serpilir (KK54). Kanamalı yaralarda kızgın soba maşası ile dağlanır (EK1-KK45). Kurtlu yaralarda ise toz tütün (Nicotiana tabacum) günde bir kez 2-3 gün boyunca yara üzerine dökülür (EK1-KK11) ya da tuz suda eritilir yara üzerine sürülür (EK1-KK30).

Uyuz: Hayvanın vücudunun çeşitli yerlerinde kaşıntı ve tüylerin dökülmesiyle anlaşılır. Deri kalınlaşmış ve tüyler yer yer dökülmüştür. Zeytin (Olea europaea) yağ1 5 gün boyunca deriye sürülür (EK1-KK4). Yanmış motor yağı bir hafta boyunca her gün etkilenmiş bölgeye sürülür (KK4,9,11,18,33,68,78). Tütün (Nicotiana tabacum) kaynatılır, uyuz olan bölge y1kanır (EK1-KK21,25,41,42,53,63,67,72,81) veya bez ile sürülür (EK1-KK33). Uyuzun olduğu bölge kar ile ovulur (EK1-KK35). İs (EK1-KK58,70), tereyağ1 (EK1-KK66) tuz (EK1-KK67) sabun (EK1-KK68), gres yağ1 (EK1-KK69), katran sürülür (EK1-KK72). Kızgın demirle dağlama yapılır. İz bırakmasına rağmen dağlama hâlâ tercih edilen bir yöntemdir (EK1-KK36).

Mantar: Kış aylarında görülen bir deri hastalığıdır (EK1-KK66). Mantarın olduğu bölge kar ile ovulur (EK1-KK35). Yanmış motor yağı bir hafta boyunca her gün etkilenmiş bölgeye bezle veya firça ile sürülür (EK1KK9,25,38,48,50,52,57,62,68,75). Bir bardak suyun içine bozadin (tarım ilac1), tuz, acı biber (Capsicum annuum), gres yağ1 karıştırılarak merhem yapılır, mantar geçene kadar sürülür (EK1-KK36). İs (EK1-KK58), sabun (EK1KK68), gres yă̆1 (EK1-KK69), katran (EK1-KK72), kükürt ve yanmış yağ karışımı (EK1-KK77) tütün (Nicotiana tabacum) kaynatılır suyu sürülür (EK1-KK72). Sacın altında biriken is toplanır, bir bez parçasının içine konulur ve mantarın üzerine sürülür (EK1-KK70). Güneşli havada hasta hayvanı dolaştırmak gerekir (EK1-KK66).

Diğer deri parazitleri (Bit, Kene, Nokra): Tütün (Nicotiana tabacum) kaynatılır, hayvanın vücudu yıkanır (EK1KK21,41,42,81) veya bez ile sürülür (EK1-KK33,80). Gres yağ1 sürülür (EK1-KK81).

Nokra hastalığı büyük baş hayvanın delirmesi olarak tanımlanır. Muska yazılır, boynuzuna bağlanır (KK21, 27,55).

Akrep ve yılan sokması, böcek ısırmast: Evcil hayvanlarda karşılaşılan akrep ve yılan sokması durumlarında, 1sırılan yere yoğurt sürülür ve yoğurt yedirilir (EK1-KK11). Böcek 1sırığında ayran içirilir (EK1-KK49). Erik ağacı (Prunus $s p$. .) sakızı kaynatılıp ağda gibi beze sürülür, bölgeye yapıştırılır (EK1-KK53).

Kırık-çıkık-ezilme-burkulma: Sığırlarda kırıkta, tuz 1sıtılır, keçe 1slatılıp bu sıcak tuzun içine konulur. Keçenin üzerine yumurta sarısı dökülerek kırık bölgeye sarılır. Sıkıca sarılıp 1 hafta bekletilir. Bir haftadan sonra ipler gevşetilir (EK1-KK5).

Hayvanlarda ezilme, travma, çarpma durumunda kazanlara yapışan duman isi kullanılır. Kazandan sıyrılan 5 gr kadar is, tereyağı ile karıştırılır günde $1 \mathrm{kez}$, iki gün ağızdan verilir (EK1-KK7). Büyükbaş hayvanlarda oluşan travmalarda $1 \mathrm{~kg}$ kadar "pirpirim" (Portulaca oleracea) 2 lt su içinde kaynatılıp hayvan iyileşene kadar günde bir kez içirilir (EK1-KK8). 
Çıkık olan eklemlerde (koyun, keçi ve buzağılarda), eklem bölgesindeki deri altına hava pompalanır. Sonra delik sakız ya da bez ile tıkanır, kapatılır (EK1-KK14).

Buzağıların ayağı burkulduğunda günde iki kez sıcak su ile sabunla ovalanır, düzelmesi sağlanır (EK1KK18). Kemik çatlakları ve burkulmalarda buğday (Triticum aestivum ) unu su ile hamur yapılır. Yarım kg kadar hamurun yarısı kızartılır, yarısı ham bırakılır. Topallayan hayvanın ayağına 12 saat boyunca bağlanır. Açıldıktan sonra masaj yapılır, topallık düzelir (EK1-KK18). Küçükbaş hayvanlarda kırık tedavisinde farklı uygulamalar yapılmaktadır. Yumurta, tuz ve un karışımı $(\mathrm{EK} 1-\mathrm{KK} 29,42,66)$ / un, su, tuz karışımı (KK41) sabitlenen kırık yere sürülür, killi (EK1-KK50) sarg1 bezi ile sarılır (EK1-KK29,41,42,50,66). Tahta parçaları ipe dizilerek kırık yer yumurta ak1 ile sabitlenir (EK1-KK40,45,48,51,65,79). Kırık tahta (EK1-KK47,52,56,60,67,68,71) veya kamış (EK1KK63) ile sabitlenir, yumurta sarıs1 (EK1-KK47,52,56,60,63,71) ya da yumurta (EK1-KK67,68) beze sürülüp sarılır (EK1-KK47,52,56,60,63,67,68,71). Mahallede ustalar tahtayla sabitleme yapar (EK1-KK43).

Tırnak çatlağı: Yanmış motor yağı (EK1-KK11), katran (EK1-KK72), gres yağı (EK1-KK38) bir hafta boyunca her gün etkilenmiş bölgeye sürülür (EK1-KK11,38,72). Sarımsak (Allium sativum) ezilir, yumurta akı ve tuz ile karıştırılır sürülür (EK1-KK63).

Topallı: Yürüme problemi ve topallık olduğunda ayçiçek (Helianthus annuus) yağı sürülür, sarılır (EK1-KK34,35). Meşe (Quercus sp.) ağacının meyvesi “mazı” dövülerek toz haline getirilir, topallayan yere serpilir (EK1-KK37).

Şap: “Tabak” olarak adlandırılır (EK1-KK29). Şap olan hayvanın ağzı ve ayakları sirke [elma (Malus sp.)/ üzüm (Vitis sp.)] ile yıkanır (EK1-KK18). Şaptan etkilenen sığır ve koyunların ayakları ve ağızları, 1 litre suya 1 avuç tuz ile hazırlanmış tuzlu suya daldırılır (EK1-KK18). Ayrıca ağız yaralarına ekmek sodası (karbonat) (EK1-KK27), domates (Solanum lycopersucum) salçası (EK1-KK40,50,62,72,76), toz haline getirilmiş "sımak" (Rhus coriaria) (EK1-KK37,64), tükenmez kalemlerin içindeki mürekkep (EK1-KK38,72) sürülür (EK1KK27,37,3840,50,62,64,72,76). Bir başka uygulamada da domates (Solanum lycopersucum) salçası, eritilmiş tereyağ1 ve tuz karıştırılarak ağza sürülür (EK1-KK56). Yemek sodası ve karbonat karıştırılarak ağız yıkanır (EK1-KK50).

Ayak yaraları için hasta hayvanlar bataklıkta (EK1-KK27), çamurda (EK1-KK49,62,64,76) yürütülür (EK1KK27,49,62,64,76). Çamaşır sodası (EK1-KK29,50), katran (EK1-KK30,50), katran ve benzin karışımı (EK1KK33), "şeb" ile göztaş1 un haline getirilip (EK1-KK33), limon tuzu, şap ve tuz dövülüp (EK1-KK33) yanık yağ (EK1-KK50,62,76), suni gübre suya kat1larak (EK1-KK56) killi toprak (EK1-KK76), "kürf” (Vitex agnus-castus L.) kaynatılıp suyu (EK1-KK72), "göztaşı" (bakırsülfat) (EK1-KK71), "göztaşl” (bakırsülfat) az su ile karıştırılır, merhem yapılarak (EK1-KK54) sürülür (EK1-KK29,30,33,50,54,56,62,71,72,76). Ayakta yara olduğunda "şava”" (şap taş1) öğütülür, toz halinde ya da sulandırılarak yaraya dökülür (EK1-KK39).

Öksürük: Kışın sık görülür. "Yel hastalı̆̆l” da denir (EK1-KK49). Büyük ve küçükbaş hayvanlarda öksürük, soğuk algınlığı, burun akıntısı, titreme ile seyreden durumlarda soğan (Allium cepa) közün içinde pişirilir, doğranır, odun külü ile karıştırılıp hayvana yedirilir (EK1-KK6). Sı ğırlara yarım litre pekmez [dut (Morus sp.) / üzüm (Vitis sp.)] yarım litre su ile karıştırılır günde 1 kez, 2 gün süre ile içirilir (EK1-KK4, 12,48). İnek ve buzağılara her gün öksürük geçene kadar dut (Morus sp.) pekmezi içirilir (EK1-KK55,70,73) veya sularına 1 yemek kaşığ dut (Morus sp.) pekmezi eklenir. Dut pekmezi öksürük ve balgamı söker (EK1-KK9). Yarım kg "pirpirim” (Portulaca oleracea) suda kaynatılıp suyu içirilir, artıkları yeme karıştırılır, yedirilir (EK1-KK15). "Işkın” (Rheum ribes) otunun kökü kaynatılıp içirilir (EK1-KK59). Yel hastalığında muska ahırın girişine kapının üzerine asılır (EK1-KK49). Hayvanın üzerine tuz serpilir, Fatiha suresi okunur, tuz ateşe atılır (EK1-KK34).

Sarılık: Hayvanlarda hararet olduğundan soğuk su ile yıkanır (EK1-KK57,60,68,71). 300 gr kadar "Sıraç” (sıraca) (Scrophularia sp.) otu 1 litre suda kaynatılır, keçilere 1 çorba kaşığı kadar, sığırlara 1 çay bardağı içirilir (EK1-KK7). Sar1lık olan hayvana dut (EK1-KK21), dut kurusu (EK1-KK23), yeşil ot (EK1-KK26), soğan (Allium cepa) ve sarımsak (Allium sativum) (EK1-KK58) ya da kuru dutun sıcak suda kaynatılıp, suyu sıkılmış hali (EK1-KK56) 
yedirilir (EK1-KK21,23,26,56,58). Sarılık gidene kadar 1 su bardağ1 tercihen dut (Morus sp.) pekmezi içirilir (EK1KK23,26,35,55-57,60,69,77). Kulaktan bir defalı̆̆ına kan akıtılır (EK1-KK47,64).

İstahsızlık: Sı̆̆ırlarda iştahsızlık durumunda soğan (Allium cepa) (EK1-KK1,16,20,39,42,56,63,72), sarımsak (Allium sativum) (EK1-KK56), kuru yonca (Medicago sp.) (EK1-KK4,56), yaş maya (EK1-KK26), saman ve kuru ot (EK1KK38), toz haline getirilmiş şeker ya da tuz (EK1-KK45), iştahı normale dönene kadar 3-4 gün süre ile kuru dut (Morus sp.) 1slatılarak (EK1-KK34) veya yarım kg "pirpirim” (Portulaca oleracea) suda kaynatılıp suyu içirilir, artıkları yeme karıştırılır, yedirilir (EK1-KK1,4,15,16,20,26,34,38,39,42,45,56,63,72). Pekmez [dut (Morus sp.) / üzüm (Vitis sp.)] (EK1-KK1,62,72), zeytin (Olea europaea) yağ1 (EK1-KK46), yumurta (KK53), "paryavşă̆l” (ac1 yavşan) (Teucrium polium) otunun (EK1-KK49) kaynatılmış suyu ya da tuz, un ve su karıştırılır bir su bardağ kadar içirilir (EK1-KK1,46,47,49,53,62,72). İştahsız atlarda dil üzerindeki dikenler çekilir, hayvan normale döner (EK1KK14) ya da kulaktan kan akıt1lır (EK1-KK40).

Halsizlik: "Keven" bitkisi bir kaç şekilde kullanılır. Dağlardan toplanan taze "keven" (Astragalus sp.) doğranıp yeme bir ay boyunca katılır (EK1-KK17). "Işkın”"ın (Rheum ribes) kökü çıkarılıp kurutulup ya sade ya da "keven" (Astragalus sp.) ile karıştırılıp hayvana yedirilir (EK1-KK55). Bir başka uygulamada da "keven” in (Astragalus sp.) dikenleri yakılıp, kökü çıkarılır. Keven kökünün 1-2 kg kadarı 2-3 günde iyice dövüldükten sonra yeme katılır (EK1KK11). Yarım litre pekmez [dut (Morus sp.) / üzüm (Vitis sp.)] yarım litre suyla karıştılıp, içirilir (EK1-KK12,55). Atlarda dil üzerindeki dikenler çekilir, hayvan normale döner (EK1-KK14).

Sancl: Hayvanlarda soğuktan ya da fazla yem yemeye bağlı olarak ya da nazar değdiğinde sanc1 olur. Hayvanlar sancılandığında yarım kg "dolık” (Malva neglecta) bir litre suda haşlanır, günde 1 kez 2 gün boyunca suyu içirilir, kalanı da yeme katılır (EK1-KK11). Sancılanan ineklere 1/3 oranında sulandırılmış sirke [elma (Malus $s p$.)/üzüm (Vitis sp.)] içirilir (EK1-KK19). Sancılanan at ve ineklere tereyağı ve pekmez [dut (Morus sp.) / üzüm (Vitis sp.)] (KK43), zeytin (Olea europaea) yağ1 (EK1-KK46), şeker ile şerbet (EK1-KK74) yapılır içirilir (EK1-KK43,46,74). Sancılanan hayvana 2-3 bardak 1sıtılmış süt içirilir (EK1-KK74). Sancılanan hayvanın kulağından akıtılır (EK1KK21). Sabah güneş doğmadan, yabani menengiç ağacından dal koparılır. Bu yapıldığında sancının geçeceğine inan1lır (EK1-KK72).

Zehirlenme: Genellikle hayvanların otladıkları yerlerde zehirli otları yemelerine bağlı olarak veya yemden kaynaklanır (EK1-KK21,23,69). Bu durumda zehirlenen hayvana pekmez [dut (Morus sp.) / üzüm (Vitis sp.)] (EK1KK23), yoğurt (EK1-KK21), ayran (EK1-KK2), ekşi ayran (EK1-KK56) veya soda (EK1-KK69) içirilir (EK1KK2,21,23,56,69). Günde 3-4 kez 2 litre kadar (EK1-KK5) ya da günde 1 defa 1 litre kadar ayran 2 gün içirilir (EK1KK12,15). Ot zehirlenmesinde sinameki (Cassia L.) kaynatılıp suyunun içirilmesi kesin çözümdür (EK1-KK22). Ayrıca kulağından kan akıtılır (EK1-KK22). Hayvan soğuk suyla yıkanır (EK1-KK23,69).

Şişkinlik: Büyükbaş hayvanlarda şişkinlikte üçte bir oranında sulandırılmış sirke [elma (Malus sp.)/ üzüm (Vitis sp.)] (EK1-KK1,19), beş tane çiğ yumurta (EK1-KK10), sinameki suyu (EK1-KK22), ayran (EK1-KK37), 1-2 litre kadar mazot (EK1-KK54), sabun suyu (EK1-KK65), maden suyu (dört şişe) (EK1-KK78,79), bir litre suda eritilen 200 gr kadar maya (EK1-KK6,57), 2-3 litre kadar ayçiçek (Helianthus annuus) yağı (EK1-KK13,54) veya yarım litre kadar ayçiçek (Helianthus annuus) yağı ile pekmez [dut (Morus sp.) / üzüm (Vitis sp.)] karışımı (EK1-KK37), karbonatlı su (EK1-KK22), soda (EK1-KK23,44,67), zeytin (Olea europaea) yağ1 (EK1-KK4,23,26,30), zeytin (Olea europaea) yağı ve toz soda (karbonat) karışımı (EK1-KK25), zeytin (Olea europaea) yağ1, sabun ve pekmez [dut (Morus sp.) / üzüm (Vitis sp.)] karışımı (EK1-KK28), yemek sodası (karbonat) (EK1-KK33), sıcak pekmez (üzüm ya da dut) ve sıvıyağ [ayçiçek (Helianthus annuus) veya zeytin (Olea europaea) yağı] (EK1-KK46), 1sıtılmış ayçiçek (Helianthus annuus) yağ1 (KK56,57), pekmez [dut (Morus sp.) / üzüm (Vitis sp.)] (EK1-KK10,16,26), yarım litre pekmez [dut (Morus sp.) / üzüm (Vitis sp.)] yarım litre su karışımı (EK1-KK11,12,17,19), bir kg pekmez [dut (Morus sp.) / üzüm 
(Vitis sp.)] (EK1-KK66,68,74) içirilir (EK1-KK1,4,6,10,11,13,16,17,19,22,23,25,26,28,30,33,37,44,46,54,56,57,65$68,74,78,79)$.

Tek seferde 50 gram kadar arap sabunu hayvana yutturulur (EK1-KK11). Ayrica arap sabunu makattan fitil gibi kullanılır (EK1-KK11). Hayvan koşturulur (EK1-KK43,45,61) veya yürütülür (EK1-KK57,61). Karnına çuvaldız batırılır, hayvan rahatlar (EK1-KK69). Koyunlara 1 su bardağ1 ayçiçek (Helianthus annuus) yağ1 içirilir (EK1KK66,70). Kulak kesilerek kan akitılır (EK1-KK39,41,45,48,65,73,81). Kulak kontrol edilir, en sicak yeri neresi ise oradan kesik atılarak kan akıtılır (EK1-KK45).

İshal: Koyunlarda ishal olduğunda kurutulmuş çay (Camellia sp.) yaprakları suda kaynatılır, iki günde 1 kez 1 lt kadar içirilir (EK1-KK3). İshal olan büyük ve küçükbaş hayvana çok demli çay (Camellia sp.) içirilmesi gerekir (EK1-KK3,54,66). 300 gr kadar "Sıraç otu”" (sıraca otu) (Scrophularia sp.) 1 litre suda kaynatılır, keçilere 1 çorba kaşığı kadar, sığırlara 1 çay bardağı içirilir (EK1-KK7). "Sımak" (Rhus coriaria) yedirilir (EK1-KK25,75) veya kaynatılıp suyu içirilir (EK1-KK75). "Sımak" (Rhus coriaria) ağacının yaprakları yakılır, külü suya konur bekletilir, süzülüp içirilir (EK1-KK63). Kuru ot (EK1-KK28,64), ezilmiş nar (Punica granatum) kabuğu (EK1-KK28), kuru çay (Camellia sp.) yeme karıştırılarak (EK1-KK28,52,66,79) ya da suyla karıştırılarak (EK1-KK44,57,62), kırılmamış arpa (Hordeum sp.) (EK1-KK47), kuru “pirpirim” (Portulaca oleracea) (EK1-KK50), limon (Citrus limon ) gibi ekşi şeyler (K EK1-K64), yoğurt (EK1-KK65), çay (Camellia sp.) demlenir içine ekmek konulup (EK1-KK69) yedirilir (EK1-KK28,44,47,50,52,57,62,64-66,69,79). Kola (EK1-KK27), kına (Lawsonia inermis) sulandir1larak (EK1KK28), meşe (Quercus sp.) ağacının meyvesi “mazı" dövülerek toz haline getirilir, suyla karıştırılıp (EK1KK29,33,37,52,78) içirilir (KK27-29,33,37,52,78). Mazı tozunun miktarı önemli, çok içirildiğinde bağırsaklara kötü etkisi olabilir (EK1-KK37). Bir bardak kadar çay (Camellia sp.), kahve (Coffea sp.) ve limon (Citrus limon) karışımı (EK1-KK41), karbonat ve kabartma tozu karıştırışımı (EK1-KK43), "paryavşă̆g”" (acı yavşan) (Teucrium polium) otu kaynatılarak suyu (EK1-KK49), “hurnif otu”"nun (Prosopis farcta) tohumu öğütülür (EK1-KK50,53) içirilir (EK1-KK41,43,49,50,53). "Cirtatan” (Ecballium elaterium) otunun meyveleri kaynatılarak suyu içirilir (EK1KK41) veya burnuna bir iki damla damlatılır (EK1-KK43).

Buzağ1 ishallerinde demli çay (Camellia sp.) (EK1-KK37,65) ya da yoğurda çay (Camellia sp.) katılarak (EK1-KK40), kahve (Coffea sp.) içirilir (EK1-KK37,40,65). Ayrıca buzağılara 2 yemek kaşığı buğday (Triticum aestivum) nişastası 2-3 gün yedirilir (EK1-KK54). Palamut öğütülüp suyla içirilir (EK1-KK70). Ağız sütü (kolostrum) içirilir (EK1-KK81).

Kabızlık: Büyük ve küçükbaş hayvanlarda kabızlık olduğunda zeytin (Olea europaea) yağ1 (EK1-KK2,75), 1 litre kadar ayçiçek (Helianthus annuus) yağı bir defada (EK1-KK8,15,54) ya da yine bir defada 1 litre kadar sıvıyă [ayçiçek (Helianthus annuus)/ zeytin (Olea europaea) yağı] (EK1-KK6,52) içirilir. Sabun rendelenip hayvanın makatına yerleştirilir (EK1-KK6) ya da arap sabunu makattan fitil gibi kullanılır (EK1-KK11). Hayvanın arka bölgesi sabunlu su ile y1kanır (EK1-KK35,36,64). Tek seferde 50 gram kadar arap sabunu hayvana yutturulur (EK1-KK11). Taze kayısı veya gün kurusu (Prunus armeniaca) 5-6 tane suda haşlanıp günde $1 \mathrm{kez}$ bir hafta boyunca içirilir (EK1KK19). Bolca şeker pancarı (Beta vulgaris) küspesi yedirilir (EK1-KK20). Pekmez [dut (Morus sp.) / üzüm (Vitis sp.)] yağ [ayçiçek (Helianthus annuus)/ zeytin (Olea europaea) yağı] karışımı içirilir (EK1-KK50). "Hiro" (Alcea striata) otu kaynatılıp suyu içirilir (EK1-KK53).

Meme Şişkinliği ve Sertleşmesi: Meme bazen şişer ve sertleşir. Bu durumda bir hafta boyunca memeye zeytin (Olea europaea) yağ1 (EK1-KK2,15,18,19, 43,79), gres yağ1 (EK1-KK56), tereyağ1 (EK1-KK59), vazelin (EK1-KK18) sürülür (EK1-KK2,15,18,19,43,56,59,79). Zeytin(Olea europaea)yağ1 ve pekmez [dut (Morus sp.)/üzüm (Vitis sp.)] kaynatılır, 1lıyınca memeye sürülür (EK1-KK42). Sicak ekmek memeye bastırılır, sonrasında zeytin (Olea europaea) yağı sürülür ve süt sağılır (EK1-KK55). “Kökün otu” (yabani sarımsak) (Allium sp.) memeye sürülür. (EK1-KK46).

Mastitis: Meme yeşil sabun ve sıcak su ile yıkanır. Temiz sıcak havlu memeye bastırılır (EK1-KK27). Zeytin (Olea europaea) yağı veya sabun ile masaj yapılır (EK1-KK57). Gres yağı sürülür (EK1-KK78). 
Meme Siğili: Yörede "bolig” olarak adlandırılır (EK1-KK1). Siğil yılan derisi ile sarılır (EK1-KK1) veya y1lan derisi yedirilir (EK1-KK2,26). Bu amaçla $20 \mathrm{~cm}$ kadar yılan derisi (yılan elbisesi) ekmek arasına katılır günde 1 defa iki gün boyunca yedirilir (EK1-KK9).

Meme siğilinde ilkbaharda çıkan, yaprakları 1spanağa benzer "nasır otu” "siğil otu” (Heliotropium europaeum) hayvana yedirilir (EK1-KK37, 51) ya da ezilip siğil üzerine sürülür (EK1-KK70). "Batuf” (Hypericum retusum) haşlanıp yedirilir (EK1-KK71). Günde 2-3 kez 4-5 gün bol tuzla siğil ovulur (EK1-KK81). Gres yağ1 ve tuz karışımı (EK1-KK55), tereyağı (EK1-KK65) siğil üzerine sürülür (EK1-KK55,65). Memede siğil sayısı kadar ipe düğüm atılır, Felak ve Nas sureleri okunur, ip toprağa gömülür (EK1-KK33). Siğil iple kökünden bağlanır, kendiliğinden düşer (EK1-KK70). Dua okunur (Hoca hangi ayeti okuduğunu söylemiyor) (EK1-KK72). Siğil kesilir, kızgın demirle dağlanır (EK1-KK78).

Kızgınlı̆̆a getirme: Kızgınlığa gelmeyen ya da yeterince kızgınlık belirtisi göstermediği düşünülen ineklere "onca" (yonca) (Medicago sp.) 20 gün boyunca yem ile birlikte bol miktarda yedirilir (EK1-KK2). Bir avuç kadar tuz haftada bir kez 2-3 hafta kadar yeme katılır (EK1-KK12,14,42,55,62). Dağdan toplanan “keven" (Astragalus sp.) doğranıp yeme 1 ay boyunca katılır (EK1-KK17). Yeşil ot (EK1-KK39) ya da sadece saman yedirilir (EK1-KK45).

Doğum sonrası bakım: Doğum sonrasında hayvan çabuk toparlansın, güçlensin diye yarım litre pekmez [dut (Morus $s p$.) / üzüm (Vitis sp.)] yarım litre suya karıştırılarak içirilir (EK1-KK8,17). Ilık su, un (Triticum aestivum) ve yağ karışımı, doğum sonrası ineklerde "çökme" (hipokalsemi) olmasın diye verilir. Bunun için 1 lt kadar suya hafif rengini değiştirecek kadar un katılır, $200 \mathrm{ml}$ kadar da ayçiçek (Helianthus annuus) yağı eklenir. Doğum yapan hayvana bir defalık içirilir (KK16). Un (Triticum aestivum) su ile bulamaç yapılır, içirilir (EK1-KK61).

Yeni doğan buzağının daha iyi gelişmesi için sütün içine incir (Ficus carica) koyup yedirilir (EK1-KK42) ya da yumurta içirilir (EK1-KK53). Doğumda buzağı ölürse, inek başka buzağıyı kabul etsin diye, ölü buzağının üzerindekiler canlı buzağıya sürülür (EK1-KK40).

Eşin düşmemesi: Halk arasında "eşi atamama” (EK1-KK65,68) "son atamama” (EK1-KK55) da denir. Doğum sonrası eşin kolay düşmesi amacıyla "pirpirim” (Portulaca oleracea) ve kabak (Cucurbita sp.) kaynatılarak suyu hayvana içirilir. Kalan posa da hayvana yedirilir. Tek seferlik bir uygulamadır (EK1-KK1). Büyükbaş hayvanlarda 1 kg kadar "pirpirim" 2 lt su içinde kaynatılıp hayvan iyileşene kadar günde bir kez içirilir (EK1-KK8). İki kg kabak 2 kg suda haşlanır, suyu içirilir, kabak da hayvana yedirilir (EK1-KK11,12). Küçükbaş hayvanlarda yarım kg "pirpirim” suda kaynatılıp suyu içirilir, artıkları yeme karıştırılır, yedirilir (EK1-KK10,13,19). "Pirpirim” (pırpar) (Portulaca oleracea) (EK1-KK32,42,81) veya buğday (EK1-KK69) yedirilir (EK1-KK32,42,69,81).

Büyük ve küçükbaş hayvanlara pekmez [dut (Morus sp.) / üzüm (Vitis sp.)] 1lık su ile karıştırılıp içirilir (EK1-KK17,30,72,75). Bir kaç gün süre ile günde 1-2 kez 1lık su içirilir (EK1-KK17,18). Kuru "pirpirim" (Portulaca oleracea), az un ve tuz ile yal yapılarak yedirilir (EK1-KK22, 23). Ardıç (Juniperus sp.) katranı ile yumurta karıştırılır, yumurta pişmeyecek kadar 1sıtılıp hayvana içirilir (EK1-KK22). Şekerli su (EK1-KK30,68,77), şekerli şerbet (EK1-KK32), un ve sıcak su karışımı (EK1-KK64), un, şeker su karışımı (EK1-KK79), elma kaynatılıp suyu (EK1-KK55) içirilir (EK1-KK30,32,55,64,68,77,79). Şeker, un, kepek karıştırılır, 1lık su eklenir hayvana içirilir (EK1-KK42,56,62,70,73) (çok verilince ishal olur) (EK1-KK42). Hayvan eşi atamayınca sarkan yavru zarlarına taş bağlanır, düşü̈n diye (EK1-KK65).

Nazar: Nazar değmesin diye muska (EK1-KK6,12,46,66,69,73,79) veya nazar boncuğu (EK1-KK69) takılır. Keskin Baba Türbesinin toprağı suya karıştırılır, hayvanlarının üzerine sürülür (EK1-KK53).

Huysuz, să̆ıma izin vermeyen hayvan: Yörede hayvanlarda muska kullanımı yaygındır. Hayvanlar huzursuzlandığı zaman muska yap1lır (EK1-KK35,40,41,45,47,48,62,63,64,66,72,75), boynuna as1lır (EK1-KK35,40,45,47,64,72), boynuzlarının arasına bağlanır (EK1-KK41,47,63) ya da Hocaya okutulur (EK1-KK45). Huysuz hayvana Gürgen 
ağacının bir parçası boynuzuna takılır (EK1-KK40). Eski bir yatırdan kazık alınıp gelinir, eve çakılır (EK1-KK41). Huysuzlanan hayvana Çamdere mevkiinde "Dilek ağacı"nın dibindeki kazığa ip bağlayıp çakıyorlar. Bu yapıldığında hayvanın iyileşeceğine inanılır (EK1-KK50).

Sağıma izin vermediğinde muska yapılır, hayvanın boynuna veya boynuzuna takılır (EK1KK5,13,23,42,43,51,52,57,58,64,65,68,70,79). Bir sopaya ip bağlanır ziyaret çevresine çakılır (KK61). Hocalar "Süt hayvan sahibinin hakkıdır, süte müdahale edilebilir" der (EK1-KK52) Muska yazılan kâğıt suda bekletilip suyu içirilir (EK1-KK5). Hoca şekere okur, hayvana okunmuş şeker yedirilir (EK1-KK43)

Muska, sütü kesilen (EK1-KK14) ya da azalan (EK1-KK35) hayvana yap1lır (EK1-KK14,35). Ayet-El-Kürsi duası muskaya yazılır (EK1-KK23). Sütte koku varsa ve mayalanmıyorsa türbeden temiz toprak alınır, süte atılırsa durum düzelir (EK1-KK51).

\section{Tartışma ve Sonuç}

Çalışma ile Adıyaman ilinde, hayvan hastalıklarında bitkisel (45), hayvansal (14) ve madensel (25) kaynaklı ilaç ham maddelerinin kullanıldığı ve bu hastalıkların tedavisinde "Dini-sihri", "Ampirik" ve "Rasyonel"e yakın tedavi yöntemlerinin uygulandığı saptanmıştır.

Kırık tedavisinde Razi'nin (10. yüzyıl) kireçle yumurta akı karışımı kullandığı bilinmektedir. Veteriner hekimliği folkloruna ait çalışmalarda $(19,24,30,32)$ yapılan incelemeler sonucu, hayvanlarda kırık tedavisinde, öncelikle kırık kemik uçlarının birleştirildiği sonra çıtalarla sabitlenerek arpa unu ve yumurta, arpa unu ve pekmez, sabun rendesi ve yumurta ak1, keçe ile yumurta akı ve bal mumu, keçi kılı ile yumurta veya tuz, yumurta ve sabun, yumurta ve tuz, un ile tuz ve yumurta, beyaz kil toprak ile yumurta ve tuz, tereyağı ile un ve yumurta gibi karışımların uygulandığı görülmektedir. Çalışmamızda kırık tedavisinde öncelikle kırık kemik uçlarının birleştirilip tahta veya kamış ile sabitlenerek keçe ile tuz ve yumurta sarısı, yumurta, tuz ve un karışımları, yumurta sarısı veya yumurta akı ile hazırlanan karışımların veya kil kullanılarak kırığın sarıldığı saptanmıştır. Elde edilen bulgular 10. yüzyıldan beri yapılagelen geleneksel uygulamaların yörede sürdürüldügünü göstermektedir. Ek olarak, Adıyaman'da uygulanan kırık tedavisinin, Anadolu'nun çeşitli yörelerinde kırık tedavisinde kullanılan ilaç ham maddeleri ve uygulanan yöntemlerle benzer, rasyonel tedavi yöntemlerine yakın bir nitelik taşıdığı söylenebilir.

Baytarnamelerde yaptığımız incelemelerde ishal tedavisinde arpa ve sumak (12), arpa kepeği ve nar (9), dövülmüş palamut ve iç yağı (14) yedirildiği, folklorik çalışmalarda ise yoğurt, yumurta, kahve, kına (8); demli çay, yumurta ak1, kola (6); yavşan otu (1); meşe kabuğu, yumurta sarısı, kola (24); limon, meşe, nar kabuğu, göztaş1, peryavşan (32); çay (2); çay ve kahve (19) kullanıldığı bildirilmiştir. Yörede ishal durumunda sumak, nar kabuğu, arpanın kullanımlarının, köklerinin baytarnamelere kadar uzandığı, veteriner hekimliği folkloruna ait çalışmalarla benzer uygulamalar olduğu saptanmıştır. "Sıraç otu" (sıraca otu), "Hurnif otu”, "Cirtatan"ın ishalde kullanımı bu çalışma ile saptanmıştır. Folklorik çalışmalarda kolostrumun ishal yapıcı etkisi bildirilse de $(19,24)$ yörede ishal olan hayvana ağız (kolostrum) içirildiği bulgusuna ulaşılmıştır. Çay, sumak, nar kabuğu, paryavşağı, kına, meşe ve kahvenin içerdikleri tanen nedeniyle büzücü etkisi olduğu (4) bilinmektedir. Yörede bu bitkiler ile yapılan ishal tedavisinin rasyonel yöntemlere yakın olduğu ileri sürülebilir.

Veteriner hekimliği folklorunda kabızlık tedavisi için pekmez, zeytinyağı, ayçiçek yağı, kayısı, sinameki (1, 8, 19, 24, 32) kullanılmış, ayrıca Elazığ ve Muş’ta hayvanın arkasına (rektum) sabun konulduğu bildirilmiştir (19, 32). Yörede yapılan uygulamaların literatürler uyumlu olduğu görüldü. Bu literatür bilgilerindeki uygulamalara ek olarak, "Hiro" otunun kaynatılıp suyunun içirildiği bulgusuna ulaşıldı. Sinameki, Hiro, zeytinyağı (4) ve kayısının (5) müshil etkisi dikkate alındığında yapılan tedavinin rasyonele yakın olduğu düşünülebilir.

Yörede uyuz tedavisinde zeytinyağı, katran ve karışımların $(10,11,14,20,31)$ ve folklorik çalışmalarda katran ve tütün, motoryağı, tereyağı, is (32) katran ve zeytinyağı (1), zeytinyağı (6), tereyağı, katran (24), katran (29) kullanımı görülmektedir. Anadolu'da uyuz tedavisinde varlığını sürdüren uygulamalarla karşılaşılan uygulamaların benzer olduğu, ayrıca zeytinyağı ve katran uygulamalarının köklerinin eski Roma Uygarlığına (26) kadar uzandığ 1 ileri sürülebilir. Kar ile ovma uygulamasının yöreye özgü bir uygulama olduğu, tütün suyu ile uyuzlu bölgenin 
yıkanmasının da tütünün içerdiği alkaloitlerden dolayı (4), parazit mücadelesinde etkili ve rasyonele yakın nitelikli bir yöntem olduğu da söylenebilir.

Şap hastalı̆̆ında folklorik literatürde sirke, katran (30) domates salçası, katran, sumak, şap, tuz, göztaş1, sirke, tereyağ (32), katran, sirke, sumak, şap (6), domates, sirke sumak, şap, çamaşır sodası, karbonat, benzin, katran (24), domates, limon (19), domates ve sumak (22), katran (3) gibi ilaç ham maddeleri kullanılmış; bunların Adıyaman'da şap hastalığında kullanılan ham maddeler ile uyumlu olduğu gözlenmiştir. "Kürf”'ün şap hastalığında kullanımı ilk kez bu çalışmada saptanmıştı. Sirke, limon, sumak, şap ve göztaşının antiseptik (6), katranın sekunder enfeksiyonları önleyici (7) özelliği göz önüne alındığında şap için kullanılan tedavi metotlarının önemli bir bölümünün rasyonel olduğu kabul edilebilir. Ancak, şapta karşılaşılan ayak yaraları için hasta hayvanların bataklıkta veya çamurda yürütülmesi uygulaması Yüksel (32)'in Elazığ'da saptadığı 'Hayvan çamurda yürütüldü̈̆ünde ayağındaki pisliğin çamura geçtiğine inanılması" ile örtüşmekte ve ampirik bir uygulama olduğu ileri sürülebilir.

Meme başı veya meme çevresindeki siğillerde dağlama yapılarak veya muska yazılarak (30) tedavi uygulandığı, hayvana yılan gömleği yedirildiği $(1,24,32)$ folklorik araştırmaların bulguları arasında yer almaktadır. $\mathrm{Bu}$ bulgular 1şı̆̆ında tedavide yılan derisinin hayvana yedirilmesi uygulamalarının folklorik araştırmaların bulgularıyla paralel olduğu ve ayrıca dini sihri tedavi yönteminin hala uygulandığı söylenebilir.

Aktinomikoz hastalığında menengiç sakızı $(32)$, katran $(3,30,32)$ kullanıldığı bulgularına ulaşıldı. Malatya, Elazığ ve Gaziantep'te (32) aktinomikoz tedavisinde şişlik üzerine tava veya tahta kazan kapağı, Orta Anadolu Bozlak Kültürü folklorunda (30) tuğla, kiremit veya bir tava ateşte kızdırılarak şişliğin üzerine bastırılması şeklindeki uygulamanın tahta parçasının şişlik üzerine bastırılıp şişliğin dağılmasının sağlanması şekline dönüştüğü düşünülebilir.

Soğan (2, 6, 8, 24), kabak (6), ebegömeci ve buğdayın (24) apse tedavinde kullanımı folklorik çalışmalarda bildirilmiştir. Adıyaman'da benzer drogların kullanıldığı; ayrıca "gilicok”, menengiç yaprağı, "iro çiçeği”, dut pekmezi, vazelin uygulaması da saptanmıştır. Ampirik bir uygulama olduğu ileri sürülebilir.

İnsan ve hayvan dışkısının ilaç olarak kullanımının Eski Mısır, Eski Roma ve Yunan Uygarlığına kadar dayandığı hatta 18. yüzyılın sonuna kadar da en gözde ilaçlardan olduğu bildirilmektedir (6). Apse tedavisinde kullanılan insan dışkısının da aradan geçen yüzyıllar hatta binyıllara rağmen insanların bildikleri ve doğru olduğuna inandıkları uygulamalara inatla bağlılıklarını sürdürdükleri hatta dışkı uygulaması ile de hayvan hastalıklarının tedavisinde süregelen menfur maddelerin bir örneği olduğu ileri sürülebilir.

Malatya'da eşi düşmeyen hayvana semizotu ve kuru soğan (32), Elazığ' da pekmez içirilip, soğan, semizotu ve elma yedirildiği (22), Orta Anadolu'da ve Konya Bölümünde soğan, yumurta yedirilip, şekerli su, pekmez içirildiği ve sarkan yavru zarlarına taş gibi ağır bir cisim bağlandığ 1 (24, 25), Muş’ta su 1lıtılıp içine tuz ve un karıştırılarak içirildiği (19) bildirilmektedir. Adıyaman'da eş düşmemesi durumunda kullanılan ilaç ham maddelerinin ve tedavi yöntemlerinin literatür ile uyumlu olduğu görülmüş ve bu uygulamaların ampirik nitelik taşıdığı söylenebilir.

Dini - sihri tedavi yöntemleri çoğunlukla nedeni anlaşılmayan, tedavilerden sonuç alınamadığında veya alınamayacağı düşünüldüğünde başvurulan yöntemlerdir (7). Yörede; Coenurus cerebralis, sanc1, siğil, Yel hastalığında, ayrıca huysuzlanan, sağıma izin vermeyen, sütü azalan, sütünde koku olan ve nazar değmesinden korkulan hayvanlara dini sihri yöntemler uygulanmaktadır.

Anadolu'da sancı tedavisinde, 19. yüzyıldan beri (13) çeşitli ağaçların (erik, iğde, kuşburnu, çam, pinar, çıtlık gibi) dallarından elde edilen sancı çubukları kullanıldığı $(1,6,24,30)$ bildirilmektedir. Eski Türklerden günümüze kalan ağaç kültüne göre ağaç, her şeyden önce var olmayı, yaşam, canlılık ve bereketi temsil etmektedir (17). Bu bağlamda çalışmada sancılanan hayvanı iyileştireceğine inanılan "sabah güneş doğmadan, yabani menengiç ağacından dal koparllması" uygulamasının, farklı yörelerde sancı çubuğu ve farklı ağaçlarla yaşatılan bu geleneğin, Adıyaman'da yöreye özgü menengiç ağacı kullanılarak ağaç kültünün günümüze bir yansıması olduğu ileri sürülebilir.

Huysuz hayvana Gürgen ağacının bir parçasının boynuzuna takılması, yatırdan kazık alınıp eve çakılması, “Dilek ă̆acı”nın dibindeki kazığa ip bağlanması da yine ağaç kültü ile ilişkilendirilebilecek örnekler arasında sayılabilir. 
Adıyaman'da hayvan hastalıklarının tedavisinde bitkisel, hayvansal ve madensel droglar ile tedaviler dışında; çıkık durumlarında çıkık olan eklem bölgesindeki deri delinerek deri altına hava üflenip sakız gibi maddelerle bölgenin tıkanması, şişkinlik, iştahsızlık, zehirlenme, sancı, sarılık gibi durumlarda kulak kesilerek kan akıtılması, koyunlarda apse, yaralanma ve uyuz olduğunda bölgenin kızgın demir ile dağlanması gibi uygulamaların kökenlerinin bazen farklılıklar gösterse de eski uygarlıklara (Eski Mısır, Roma), baytarnamelere (9, 10, 14, 20, 21, 31) ve folklorik çalışmalara $(1,6,19,23,24,32)$ dayandığ ve yörede hala uygulamalara devam edildiği söylenebilir.

Veteriner hekimliği folkloruna ait çalışma $(1-3,6-8,19,22-25,29,30,32)$ ve baytarnamelerde $(9-12,14,20$, 21, 31) yapılan taramalar sonucu bitkisel ilaç ham maddelerden "Ardıç katranı" eşin düşmemesi, "Ayçiçeği" yara, sanc1 giderici, güçten düşen hayvanı kuvvetlendirmek, "Batuf” siğil, "Buğday" ishal, "Domates" boynuz kırı̆̆ 1 , "Erik" yara, akrep / yılan sokması, aktinomikoz, "Hiro" kabızlık, "Kabak" eşin düşmemesi, "Paryavşağı otu”" iştahsızlık, "Keven” kızgınlığa getirme, güçten düşen hayvanı kuvvetlendirmek, "Kına” ishal, "Kürf” şap hastalığı, "Pirpirim" iştahsızlık ve yara, "Işkın”" güçten düşen hayvanı kuvvetlendirmek, "Straca otu” ishal ve sarılık, "Siğil otu” siğil, "Soğan" burun akıntısı, "Sumak" şişkinlik, "Üzüm” kabızlık, "Yonca” kızgınlığa getirme, "Yllan derisi" apse, "Tereyağl" siğil ve sancı, "Yumurta" karın şişliği, apse ve hayvanı kuvvetlendirme, "Ayran" akrep / yılan sokmas1, "Kolostrum" ishal, "Balmumu" boynuz kırı̆̆1, "Hayvan derisi" yaralanma ve travma, "Süt" sanc1, "Gres yă̆l” siğil ve deri çatlakları, "Karbonat" ishal, "Maden suyu” zehirlenme, "Motor yă̆l” boynuz kırı̆̆ı, "Mürekkep" deri yaralanmaları ve şap, "İs" mantar, "Vazelin” apse, "İncir” yeni doğan buzağının güçlenmesi amaçlı kullanılması ilk defa bu çalışma ile saptanmıştır.

Sonuç olarak, Adıyaman ilinin veteriner hekimliği folkloru açısından kökenleri Eski uygarlıklara ve baytarnamelere uzanan zengin bir birikime sahip olduğu, yörede hayvan hastalıklarının tedavisinde hala ampirik ve dini-sihri yöntemlerin uygulandığg ayrıca günümüz modern tedavi yöntemlerine benzer uygulamaların da yapıldığı ileri sürülebilir.

\section{Teşekkür}

Saha çalışmaları boyunca misafirperverliklerden dolayı Adıyaman halkına, Veteriner hekim Ziyat Özeyranoğlu, Veteriner hekim Sırrı Öztürk, Veteriner hekim Veysi Öztürk ve Veteriner hekim Yusuf Onur Yıldırım nezdinde tüm veteriner hekimlere teşekkür ederim.

\section{Çıkar Çatışması Beyanı}

Yazarlar herhangi bir çıkar çatışması veya finansal destek bildirmemiştir

\section{Yazar Katkısı Beyanı}

Fikir/kavram: Seda Çavuş ALAN, Abdullah ERYOL

Deney tasarımı: Seda Çavuş ALAN, Abdullah ERYOL

Denetleme/Danışmanlık: Rahşan ÖZEN

Veri toplama: Seda Çavuş ALAN, Abdullah ERYOL

Veri analizi ve yorum: Seda Çavuş ALAN, Abdullah ERYOL, Rahşan Özen

Kaynak taraması: Seda Çavuş ALAN, Abdullah ERYOL

Makalenin yazımı: Seda Çavuş ALAN, Rahşan ÖZEN

Eleştirel inceleme: Rahşan ÖZEN

\section{Etik Onay}

$\mathrm{Bu}$ makaledeki sunulan verilerin, bilgilerin ve dokümanların akademik ve etik kurallar çerçevesinde elde edildiği, tüm bilgi, belge, değerlendirme ve sonuçlarının bilimsel etik ve ahlak kurallarına uygun olarak sunulduğuna dair yazarlardan etik beyan alınmıştır. 


\section{Kaynaklar}

1. Arslan ES (1998): Ege Bölgesi Folklorunda Veteriner Hekimliği ve Hayvancıllk Üzerine Araştırmalar. Doktora Tezi, Ankara Üniversitesi, Sağ Bil Enst, Ankara.

2. Aslım G, Sinmez ÇÇ (2017): Aksaray İli Folklorunda Aksaray Malaklısı Yetiştiriciliği. Eurasian J Vet Sci, 33(3), 148-157.

3. Aveı A, Özen R (2016): Kara Hekim: Katran'in Antalya Veteriner Hekimliği Folklorunda Hayvan Hastalıklarının Tedavisinde Kullanımı. Firat Univ J Health Sci, 30(1), 39-44

4. Baytop T (1984): Türkiye'de Bitkiler ile Tedavi (Geçmişte ve Bugün). İstanbul Üniversitesi Yayınları, Istanbul.

5. Deniz L, Serteser A, Kargığlu M (2010): Uşak Üniversitesi ve yakın çevresindeki bazı bitkilerin mahalli adlarl ve etnobotanik özellikleri. AKÜ Fen Bilimleri Dergisi 1, 57-72.

6. Dinçer F (1967): Türk Folklorunda Veteriner Hekimliği Üzerine Araştırmalar. Doktora Tezi, Ankara Üniversitesi Fakültesi Yayınları: 214, Ankara.

7. Dinçer F (1976): Türk folklorunda veteriner hekimlik (beş doğu ilimizde yeni örnekleriyle). İn. I. Ulusal Türk Folklor Kongresi Bildirileri, Cilt 4, DSİ Basım ve Foto Film İşletme Müdürlüğü, Ankara.

8. Doğanay S (1982): Afyon Folklorunda Veteriner Hekimlik Araştırma ve İncelemeleri. İn. II.Milletlerarası Türk Folklor Bildileri Cilt 4: G. Ü. Basın-Yayın Yüksekokul. Basımevi, 131-151, Ankara.

9. Erk N (1959): Íslam Medeniyet Çağında Veteriner Tababette Gelişmeler ve "Naseri". Doçentlik Tezi, Ankara Üniversitesi Veteriner Fakültesi Yay: 109, Ankara.

10. Erk N (1961): “Tuhfetülfarisin Fi Ahval-i Huyul El-Mücahaddin” Adl Kitabın İlimler Tarihi Yönünden Incelenmesi. Ankara Üniversitesi Dil ve Tarih-Coğrafya Fakültesi Dergisi, 17(4), 495-511.

11. Erk N (1962): A Study of the Veterinary Section İbn Al-Awwam's "Kitab al-Fâlâhâ". Ankara Üniv Vet Fak Derg, 8(3), 241-250.

12. Erk N (1962): Dokuzuncu yüzyıla ait "Kitab al-haly val-baytara” üzerinde inceleme. Ankara Üniv Vet Fak Derg, Cilt VIII, No. 4, Ankara.

13. Erk N (1972): Türkiye'de veteriner hekimlik, Godlewsky ve Sommer. Ankara Üniversitesi Veteriner Fakültesi Yayınları: 281, Ankara Üniversitesi Basımevi, Ankara.

14. Erk N, Dinçer F (1967): XV inci ya da XVI ıncı Yüzyıla Ait Olduğu Sanılan Bir Baytarname İncelemesi. Ankara Üniv Vet Fak Derg, Cilt: XIV, No:2, Ankara.

15. Furkan MK (2016): Adlyaman ilinde yetişen bazı bitkilerin etnobotanik özellikleri. Yüksek Lisans Tezi, Adıyaman Üniversitesi Fen Bil Enst, Adıyaman.

16. Gelse A (2012): Adlyaman ve çevresinin etnobotanik özellikleri. Yüksek Lisans Tezi, Yüzüncü Y1l Üniversitesi Fen Bil Enst, Van.

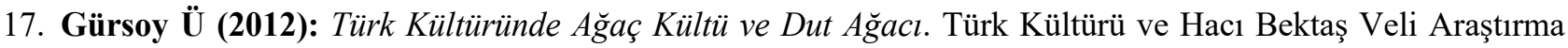
Dergisi, 61, 43-54.

18. Karasszon D (1988): A concise history of veterinary medicine. Akademiai Kiado, Budapest.

19. Kardaş C (2019): Muş'ta halk veterinerliği ve geleneksel tedavi yöntemleri. Ürün Yayınları, Ankara.

20. Özen A (1999): Milli Kütüphanedeki yazma baytarnameler üzerinde tarihsel incelemeler. Doktora Tezi, Ankara Üniversitesi, Sağlık Bilimleri Enstitüsü, Ankara.

21. Özen A Taşkın Ü (2010): Baytarname-i Kenan Efendi. Bizim Büro Basımevi, Ankara.

22. Özen R, Doğan G (2017): Elazı̆̆ yöresinde veteriner hekimliği folklorunda kullanılan bitkisel ilaç ham maddeleri. Lokman Hekim Dergisi, 7(3),166-177.

23. Salman M (1948): Halk hekimliği ve halk veterinerliği. İn: Milli Kültür Araştırmaları: VIII, Ulus Basımevi, 35-66, Ankara.

24. Sinmez ÇÇ (2011): Bozlak kültüründe folklorik veteriner hekimliği ve hayvancıllk üzerine araştırma. Doktora Tezi, Selçuk Üniversitesi Sağ Bil Enst, Konya. 
25. Sinmez ÇÇ, Yaşar A (2016): Konya Bölümü folklorik veteriner hekimliğinde ruminantlarda doğum bilgisi ve jinekoloji. Kafkas Univ Vet Fak Derg, 22(3), 409-415.

26. Smithcors JF (1958): Evolution of the veterinary art. Balliere, Tindall and Cox, London.

27. Şar S (2011): Bazı üzümsü meyvelerin kullanımlarının eczacılık ve tıp tarihi açısından incelenmesi. Lokman Hekim Dergisi, 1(2), 1-6.

28. Tavukçu H (2016): Geleneğin yeniden keşfi bağlamında halk hekimliği (Ankara kent örneği). Yüksek Lisans Tezi, Hacettepe Üniversitesi Sos Bil Enst, Ankara.

29. Yaşar A, Sinmez CÇ, Aslım G (2015): $\dot{I}_{c ̧}$ Anadolu Bölgesi Konya Bölümü folklorunda ruminantların paraziter hastallklarl ve tedavi yöntemleri. Kafkas Univ Vet Fak Derg, 21(1), 1-7.

30. Yerlikaya H (2002): Elazı̆̆ ve çevresinde hayvan hastalıklarında halk hekimliği üzerine araştırmalar. Kafkas Üniversitesi Veteriner Fakültesi Dergisi. 8(2), 131-138.

31. Yiğit A (2011): İlm-i Fürusiyet İsimli Baytarnamenin Veteriner Hekimliği Tarihi, At Yetiştiriciliği ve Hastalıklar Açısından İncelenmesi. Doktora Tezi, Selçuk Üniversitesi Sağ Bil Enst, Ankara.

32. Yüksel E (2012): Aşağ Fırat Havzasında veteriner hekimliği folkloru üzerine araştırmalar. Doktora Tezi, Frrat Üniversitesi Sağ Bil Enst, Elazı̆̆. 


\section{EK-1: Kaynak Kiși (KK) Listesi}

KK1.Mehmet Keskin, 42 yaşında, önlisans, çiftçi. KK2.Muhammed Arıc1,43 yaşında, önlisans, serbest. KK3.Celal Kaplan,42 yaşında, lisans, öğretmen. KK4Mustafa Avcı, 51 yaşında, ortaokul, esnaf. KK5.İbrahim Sel, 60 yaşında, ilkokul, çiftçi. KK6.Yusuf Sel, 32 yaşında ortaokul, serbest. KK7.Süleyman Öcal, 33 yaşında, ilkokul, çiftçi. KK8.Mehmet Gazi Gümüş, 42 yaşında, ortaokul, çiftçi. KK9.Yahya Yaylagül, 38 yaşında, ortaokul, serbest. KK10.Mahmut Keskin, 56 yaşında, ilkokul, hayvan ticareti. KK11.Mikail Keskin, 41 yaşında, ortaokul, çiftçi. KK12.Hüseyin Öcal, 50 yaşında, ilkokul, çiftçi. KK13.Hacı Bulut, 46 yaşında, ilkokul, çiftçi. KK14.Ramazan Ces,64 yaşında, ilkokul, çiftçi. KK15.Ali Çitil, 63 yaşında, ilkokul, çiftçi. KK16.Mehmet Bulut, 36 yaşında, ilkokul, çiftçi. KK.17.Meryem Bulut, 65 yaşında, okur-yazar değil, hayvancılık. KK18.Mehmet Şükrü Acar, 43 yaşında, önlisans, çiftçi. KK19.Mustafa Avc1 40 yaşında, ortaokul, çiftçi. KK20.Mustafa Yanık,47 yaşında, ilkokul, çiftçi. KK21.Yusuf Erbil. 70 yaşında, ilkokul, hayvancılık. KK22.Mustafa Kuzu, 72 yaşında, ilkokul, hayvancılık. KK23.Çetin K1lıç, 43 yaşında, lise, çiftçi. KK24.Bekir Sarımsak, 65 yaşında, okur-yazar, at yetiştiricisi. KK25. Mustafa Şahin. 34 yaşında, lise, serbest. KK26.Nazım Güler, 62 yaşında, okur-yazar değil, hayvancılık. KK27. Gaffar Güler. 37 yaşında, lise, hayvancılık. KK28.Abuzer Fırat, 60 yaşında, ilkokul, hayvancılık. KK29.Ahmet Özilik, 69 yaşında, okur-yazar değil, çiftçi. KK.30.Ali Yüce. 55 yaşında, lisans, emekli. KK31.Abdurrahman Erkmen.65 yaşında, ilkokul, çiftçi. KK32.Ali Güven,60 yaşında, ilkokul, hayvancılık. KK33.Mehmet Kamış11, 5 yaşında, lise, hayvancılık. KK34.Hacı Yetiş. 25 yaşında, ortaokul, serbest. KK35.Abdurrahman Tabba.70 yaşında, ilkokul, çiftçi. KK.36, Ensar Işık,42 yaşında, ortaokul, çiftçi. KK37.Hamza Gitmez,62 yaşında, ilkokul, çiftçi. KK38. Özcan Ergün,40 yaşında, ilkokul, çiftçi. KK39.Osman Bilgin, 51 yaşında, ilkokul, çiftçi. KK40. Murat Keskin, 38 yaşında, ilkokul, çiftçi. KK41.Abdurrahman Bilgin, 54 yaşında, okur-yazar, çiftçi. KK42. İsmail Demir, 37 yaşında, ortaokul, çiftçi. KK43.Nihat Solak, 54 yaşında, ilkokul, çiftçi. KK44.Halil Yavcık,47 yaşında, ilkokul, hayvancılık. KK45.Mahmut Yaman,52 yaşında, okur-yazar, çiftçi. KK46. Hacı Öztürk, 63 yaşında, ilkokul, çiftçi. KK47.Mustafa Mamayi,32 yaşında, ilkokul, çiftçi. KK48. Zafer Öztürk, 39 yaşında, ortaokul, çiftçi. KK49. Mustafa Er, 61 yaşında, okur-yazar, çiftçi. KK50.Ömer Ekici, 54 yaşında, ortaokul, muhtar. KK51.Orhan Yılmaz, 48 yaşında, ortaokul, çiftçi. KK52.Tuncay Bozkurt, 35 yaşında, lise, hayvancılık. KK53.Hamit Saydam, 45 yaşında, lise, muhtar. KK54.Abuzer Çağlın, 40 yaşında, ilkokul, çiftçi. KK55.Arif Gül, 59 yaşında, ilkokul, çiftçi. KK56, Ahmet Balkanöz, 44 yaşında, ortaokul, çiftçi. KK57. Ömer Mamayi, 28 yaşında, ortaokul, çiftçi. KK58.Mehmet İpek, 53 yaşında, ilkokul, çiftçi. KK59.Mehmet Özbulut, 62 yaşında, ilkokul, çiftçi. KK60.Ali Akarslan, 47 yaşında, ortaokul, çiftçi. KK61.Mehmet Akarslan, 56 yaşında, ilkokul, çiftçi. KK62.Abdullah Yıldız, 55 yaşında, lise, hayvancılık. KK63.Abdülmecid Ertan, 45 yaşında, ortaokul, çiftçi. KK64.Faik Erdal, 62 yaşında, ilkokul, hayvancılık. KK65.Şevket Berk, 51 yaşında, ilkokul, çiftçi. KK66.Mehmet Delikanlı, 62 yaşında, ilkokul, çiftçi. KK67.Saadet Tepe, 55 yaşında, ilkokul, hayvancılık. KK68.Nazif Bilgin, 49 yaşında, ilkokul, hayvancılık. KK69.Şevket Karadede, 44 yaşında, lise, çiftçi. KK70.Necati Yolcu, 43 yaşında, ilkokul, çiftçi. KK71.Ömer Bilgin, 27 yaşında, ortaokul, hayvancılık. KK72.İhsan Kaya, 50 yaşında, ortaokul, hayvancılık. KK73.Baki Kaya, 50 yaşında, ilkokul, serbest. KK74.Mehmet Serkaya, 68 yaşında, ilkokul, çiftçi. KK75.Basri Gürbüz, 41 yaşında, lise, çiftçi. KK76.Yılmaz Özgen,33 yaşında, ilkokul, çiftçi. KK77.Salih Erdem, 44 yaşında, lise, hayvancılık. KK78.Mehmet Nuri Ertaş, 64 yaşında, ilkokul, hayvancılık. KK79.Orhan Yılmaz, 49 yaşında, okur-yazar, hayvancılık. KK80.Osman Erşahin, 43 yaşında, ilkokul, hayvancılık. KK81. Murat Kılıç, 41 yaşında, ilkokul, hayvancılık. 